Gut, 1986, 27, 756-764

Liver and biliary

\title{
Impaired acetaldehyde metabolism in patients with non-alcoholic liver disorders
}

\author{
K MATTHEWSON, H AL MARDINI, K BARTLETT, AND C O RECORD \\ From the Gastroenterology Unit and Department of Clinical Biochemistry and Metabolic Medicine, Royal \\ Victoria Infirmary and University of Newcastle Upon Tyne
}

SUMmaRY In order to determine the specificity of abnormalities of alcohol metabolism in patients with alcoholic liver disease, blood acetaldehyde concentrations after oral ethanol challenge and the activities of alcohol metabolising enzymes in liver biopsy samples have been determined in patients with alcoholic liver disease and a wide variety of non-alcoholic liver disorders. Significant decreases in hepatic cytosolic aldehyde dehydrogenase activity were associated with significant increases in acetaldehyde concentrations after ethanol in both patient groups compared with control subjects. There was a significant correlation between hepatic cytosolic aldehyde dehydrogenase and mean blood acetaldehyde concentration 30-180 min after ethanol ingestion $(y=17.4-0.45 x ; r=-0.56 ; p<0.01)$ confirming the importance of this enzyme in controlling blood acetaldehyde concentrations. These findings suggest that disturbances in alcohol metabolism in patients with alcoholic liver disease are the consequence of liver damage rather than a specific abnormality predisposing to alcohol induced liver injury.

Acetaldehyde, the first product of ethanol metabolism is a highly toxic substance ${ }^{1-4}$ and not surprisingly is considered a possible mediator of alcoholic liver damage. Although the assay of acetaldehyde in biological fluids is difficult and earlier techniques have been criticised, ${ }^{5-8}$ there are now several reports of raised blood acetaldehyde concentrations in alcoholics after both intravenous ${ }^{910}$ and oral ${ }^{11}$ administration of ethanol. Such rises could be explained by either increased ethanol or decreased acetaldehyde oxidation.

Acetaldehyde is oxidised by the enzyme aldehyde dehydrogenase (ALDDH) principally within the liver. The enzyme is present in two forms, one mitochondrial and the other cytosolic and a decrease in the hepatic activity of this enzyme, particularly the cytosolic form, has been shown in alcoholic liver disease. ${ }^{12}{ }^{13}$ It has been suggested that this reduced enzyme activity is responsible for the raised acetaldehyde concentrations seen in alcoholics. ${ }^{11}$ Reduced hepatic ALDDH activity could be a pre-existing abnormality which predisposes to alcoholism or alcoholic liver injury, ${ }^{13}$ but might simply be a non-specific consequence of liver damage.

Address for correspondence: Dr C O Record, Gastroenterology Unit, Royal Victoria Infirmary, Queen Victoria Road, Newcastle-upon-Tyne NE1 4LP.

Received for publication 11 October 1985
In order to assess the specificity of this abnormality to alcoholic liver disease we have assayed the hepatic cytosolic alcohol and acetaldehyde metabolising enzymes in patients with alcoholic liver disease and patients with a variety of acute and chronic non-alcoholic liver disorders. We have also developed a new simplified assay to measure blood ethanol and acetaldehyde concentrations after ethanol loading in patients with the same variety of liver disorders.

\section{Methods}

\section{PATIENTS}

Enzyme studies were carried out on 48 subjects who were undergoing diagnostic liver biopsy. Of these, 20 had alcoholic liver disease (ALD), 20 had non-alcoholic liver disorders (NALD) and eight were normal controls. The patients with ALD included 14 with an established cirrhosis, three with hepatitis but no cirrhosis, and three with steatosis only. Seven ALD patients claimed to have abstained from alcohol for longer than two months whilst the other 13 admitted to or their relatives indicated continuing drinking. The patients with NALD included seven with primary biliary cirrhosis (PBC), six with chronic active hepatitis (CAH), four with paracetamol induced liver damage, two with cryp- 
togenic cirrhosis and one with obstructive jaundice. Active chronic hepatitis patients all suffered from the autoimmune variety and were under treatment with prednisone $5-10 \mathrm{mg} /$ day. All NALD patients took less than $100 \mathrm{~g}$ ethanol weekly. Subjects were classed as normal controls for the purposes of this study if they had normal liver function tests and normal liver histology at the time of study. Details of all the above patients are shown in Table 1.

Seven of the controls had liver biopsies taken during intra-abdominal surgery for benign conditions when the surgeon wished to exclude liver disease. All other liver biopsies were taken in the standard fashion using a Trucut needle. Biopsies from the patients with acute paracetamol poisoning were delayed until the prothrombin time had returned to within four seconds of normal. Liver biopsy samples were divided and one portion sent for routine histology. The other portion was immediately wrapped in parafilm and placed under crushed ice. A cytosolic fraction was prepared ${ }^{14}$ and aldehyde dehydrogenase activity was assayed at $30^{\circ} \mathrm{C}$ by the method of Blair and Bodley ${ }^{15}$ with the addition of pyrazole $1 \mathrm{mmol} / \mathrm{l}$ and rotenone $6 \mu \mathrm{mol} / \mathrm{l}$ to inhibit alcohol dehydrogenase and NADH oxidase respectively. Alcohol dehydrogenase activity $(\mathrm{ADH})$ was assayed at $30^{\circ} \mathrm{C}$ in the reverse direction as described by Lange ${ }^{16}$ and lactate dehydrogenase (LDH) was assayed by the method of Reeves and Fimognari. ${ }^{17}$ Protein was measured using the Lowry technique. ${ }^{18}$ Enzyme activity was expressed in $\mathrm{mU}$ of enzyme activity per milligram of protein present, where $1 \mathrm{mU}$ corresponds to $1 \mathrm{nmol}$ of substrate metabolised per minute. All enzyme assays were done within six hours of liver biopsy.

Ethanol loading studies were undertaken in 40 subjects, including 22 who had the liver biopsy studies. Of the 40 subjects, 14 had ALD, 14 had NALD and 12 were normal controls. Only one of the ALD and none of the NALD patients had clinically detectable ascites at the time of study. One ALD and two NALD patients were taking diuretics. Five ALD patients claimed abstention for longer than two months and nine were thought to be continuing drinkers. All NALD patients took less than $100 \mathrm{~g}$ ethanol weekly. For ethanol loading experiments subjects were classed as normal controls if they had normal liver function tests, consumed less than $100 \mathrm{~g}$ of ethanol weekly, and were not known to have liver disease. No subject had undergone gastric surgery or any procedure which might have altered the rate of gastric emptying. Details of these subjects are shown in Table 2.

Blood ethanol and acetaldehyde concentrations were assayed simultaneously by a simplified gas chromatographic assay based on the method of Von Wartburg and Ris. ${ }^{19}$ After an overnight fast, subjects had a large gauge butterfly placed in a peripheral arm vein. Baseline blood samples were taken and then an ethanol load, $0.7 \mathrm{~g} / \mathrm{kg}$ body weight was taken orally. The ethanol, which was diluted in orange juice to make it palatable was drunk over a 10 minute period. Further blood samples were taken at 30 minute intervals over a three hour period. Blood was taken by allowing it to drip directly from the butterfly into $20 \mathrm{ml}$ septum vials (Pierce) containing $5 \mathrm{ml}$ of ice cold $0.61 \mathrm{~mol} / 1$ perchloric acid (PCA) and $20 \mathrm{mmol}$ freshly prepared L-cysteine. These were immediately sealed with Teflon coated rubber stoppers (Pierce \& Warriner (UK) Ltd), thoroughly mixed and frozen on dry

Table 1 Details of patients undergoing liver biopsy studies

\begin{tabular}{|c|c|c|c|c|c|c|c|}
\hline & \multirow[b]{2}{*}{$\begin{array}{l}\text { Male: } \\
\text { Female } \\
\text { ratio }\end{array}$} & \multicolumn{6}{|c|}{ Mean (range) } \\
\hline & & Age & $\begin{array}{l}\text { Cirrhotic } \\
\text { (no) }\end{array}$ & $\begin{array}{l}\text { Aspartate } \\
\text { amino- } \\
\text { transferase } \\
(N R=0-37 \quad \mathrm{U} / \mathrm{l})\end{array}$ & $\begin{array}{l}\text { Alkaline } \\
\text { phosphatase } \\
(N R=30-130 \quad \mathrm{U} / \mathrm{l})\end{array}$ & $\begin{array}{l}\text { Prothrombin } \\
\text { ratio }\end{array}$ & $\begin{array}{l}\text { Albumin } \\
(N R=34-50 \mathrm{~g} / l)\end{array}$ \\
\hline $\begin{array}{l}\text { Alcoholic liver disease } \\
(n=20)\end{array}$ & $14: 6$ & $51(31-66)$ & 14 & $67(20-144)$. & $150(63-514)$ & $84 \%(58-100)$ & $39(30-48)$ \\
\hline $\begin{array}{l}\text { Primary biliary cirrhosis } \\
(n=7)\end{array}$ & $0: 7$ & $59(43-69)$ & 4 & $90(43-230)$ & $664(246-1470)$ & $86 \%(74-100)$ & $41(37-44)$ \\
\hline $\begin{array}{l}\text { Chronic active hepatitis } \\
(n=6)\end{array}$ & $0: 6$ & $54(28-73)$ & 2 & $43(18-93)$ & $105(42-141)$ & $97 \%(85-100)$ & $41(38-46)$ \\
\hline $\begin{array}{l}\text { Paracetamol poisoning } \\
(n=4) \\
\text { Other non-alcoholic }\end{array}$ & $0: 4$ & $28(19-35)$ & 0 & $1868(123-5800)$ & $109(81-142)$ & $47 \%(29-65)$ & $44(39-48)$ \\
\hline $\begin{array}{l}\text { liver disorders }(n=3) \\
\text { Normal controls }(n=8)\end{array}$ & $\begin{array}{l}2: 1 \\
2: 6\end{array}$ & $\begin{array}{l}63(48-74) \\
47(34-60)\end{array}$ & $\begin{array}{l}2 \\
0\end{array}$ & $\begin{array}{l}91(31-109) \\
23(12-34)\end{array}$ & $\begin{array}{r}128(67-169) \\
68(27-120)\end{array}$ & $82 \%(74-100)$ & $39(37-42)$ \\
\hline
\end{tabular}


Table 2 Details of patients undergoing ethanol loading studies

\begin{tabular}{|c|c|c|c|c|c|c|c|}
\hline & \multirow[b]{2}{*}{$\begin{array}{l}\text { Male: } \\
\text { Female } \\
\text { ratio }\end{array}$} & \multicolumn{6}{|c|}{ Mean (range) } \\
\hline & & Age & $\begin{array}{l}\text { Cirrhotic } \\
\text { (no) }\end{array}$ & $\begin{array}{l}\text { Aspartate } \\
\text { amino- } \\
\text { transferase } \\
(N R=0-37 \text { U/l) }\end{array}$ & $\begin{array}{l}\text { Alkaline } \\
\text { phosphatase } \\
(N R=30-130 \quad \text { Ull) }\end{array}$ & $\begin{array}{l}\text { Prothrombin } \\
\text { ratio }\end{array}$ & $\begin{array}{l}\text { Albumin } \\
(N R=34-50 \mathrm{~g} / \mathrm{l})\end{array}$ \\
\hline $\begin{array}{l}\text { Alcoholic liver disease } \\
\quad(n=14)\end{array}$ & 9:5 & $47(31-64)$ & 12 & $48(11-103)$ & $121(47-239)$ & $82 \%(74-100)$ & $38(30-42)$ \\
\hline $\begin{array}{l}\text { Primary biliary cirrhosis } \\
(n=6)\end{array}$ & $0: 6$ & $60(43-72)$ & 4 & $95(43-230)$ & $713(260-1470)$ & $95 \%(85-100)$ & $37(27-43)$ \\
\hline $\begin{array}{l}\text { Chronic active hepatitis } \\
(\mathrm{n}=4)\end{array}$ & $0: 4$ & $53(30-73)$ & 0 & $49(18-193)$ & $108(65-141)$ & $100 \%$ & $39(37-44)$ \\
\hline $\begin{array}{l}\text { Paracetamol poisoning } \\
(n=4)\end{array}$ & $1: 3$ & $30(19-40)$ & 0 & $1612(123-5800)$ & $100(60-128)$ & $36 \%(16-50)$ & $39(36-45)$ \\
\hline $\begin{array}{l}\text { Normal controls } \\
(n=12)\end{array}$ & $6: 6$ & $42(24-60)$ & 0 & $19(10-32)$ & $67(42-121)$ & & \\
\hline
\end{tabular}

ice after the addition of the internal standard, 1-propanol $(10 \mu \mathrm{mol})$ which was freshly prepared for each assay. The quantity of blood collected (about $2 \mathrm{ml} ; 20$ drops) was determined by weighing.

For analysis, samples were heated to $60^{\circ} \mathrm{C}$ for 30 minutes and $1.0 \mathrm{ml}$ of head space gas was injected onto the GLC column. A Carlo-Erba model FV 350 gas chromatograph fitted with a flame ionisation detector and a glass column $(2.5 \times 3 \mathrm{~mm}$ ID) packed with poropak Q 80-100 mesh was used. Operating conditions were as follows:- injector port, detector temperature and column temperature $150^{\circ} \mathrm{C}$; gas flow rates: nitrogen carrier gas $30 \mathrm{ml} / \mathrm{min}$, hydrogen
$30 \mathrm{ml} / \mathrm{min}$ and air $240 \mathrm{ml} / \mathrm{min}$. Detector sensitivity was $1 \times 10-20$ depending on the sample, while retention times for ethanol, acetaldehyde and 1propanol were $1.5,2.5$, and 6.3 minutes respectively. Samples were injected into the column with a $1 \mathrm{ml} \mathrm{A} 2$ pressure lok gas syringe (Precision Sampling Corporation USA) which was heated to $60^{\circ} \mathrm{C}$ before sampling to prevent condensation of the sample within the syringe barrel. The output from the chromatograph was displayed on a strip chart recorder. Peak areas were determined using an electronic integrator (Infatronics (UK) Model 308).

The ethanol, acetaldehyde and 1-propanol were
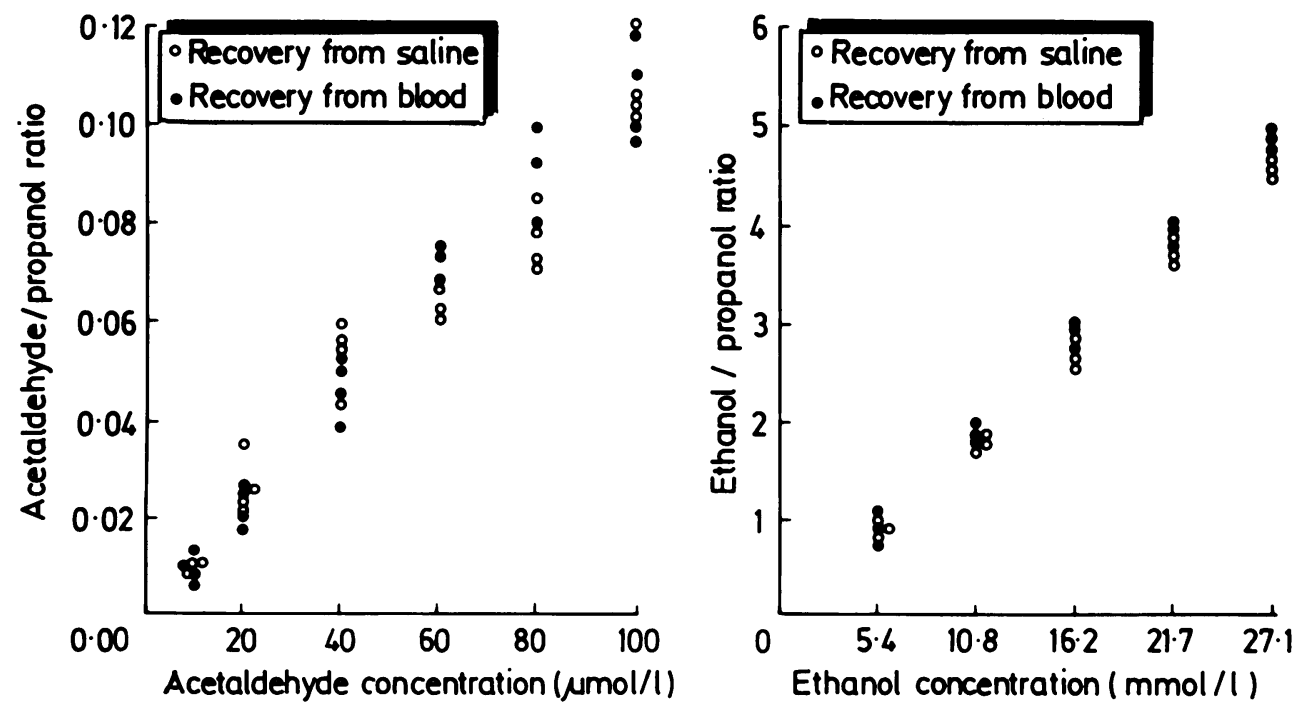

Fig. 1 Recovery curves for acetaldehyde and ethanol from saline and blood. 
well resolved by the GC, and there was no interference from endogenous compounds in the blood.

\section{STANDARD CURVES AND RECOVERY STUDIES}

Standard curves were constructed by spiking saline and blood with ethanol and acetaldehyde in the concentration ranges 5.4-27.2 $\mathrm{mmol} / \mathrm{l}$ and $10-100 \mu \mathrm{mol} / \mathrm{l}$ respectively. For each standard curve the ethanol/propanol and acetaldehyde/propanol peak area ratios were calculated and plotted against the amounts added, as shown in Figure 1. For each blood sample, the concentrations of ethanol and acetaldehyde were determined by calculation of peak area ratios and interpolation on the standard curves using the slope and intercept of the line of best fit obtained by regression analysis. Standard curves were run for each assay. The recovery of ethanol and acetaldehyde from blood was very similar to the recovery from saline (Fig. 1).

The recovery of acetaldehyde $(16 \mu \mathrm{mol} / \mathrm{l})$ added to saline and blood in the presence and absence of $20 \mathrm{mmol} / \mathrm{l}$ ethanol was also studied. The recovery of acetaldehyde from saline, blood and from blood plus $20 \mathrm{mmol} / \mathrm{l}$ ethanol were respectively $16 \cdot 0 \pm 0 \cdot 3$, $16.4 \pm 0.6$ and $16 \cdot 6 \pm 0.5 \mu \mathrm{mol} / \mathrm{l}$ (mean $\pm \mathrm{SE}, \mathrm{n}=5$ ). The results show that there was no non-enzymatic formation of acetaldehyde from ethanol, and that there were no losses of acetaldehyde during the course of the assay.

The reproducibility of the method with respect to acetaldehyde was examined in nine samples to which acetaldehyde had been added to a final concentration of $10 \mu \mathrm{mol} / \mathrm{l}$. The coefficient of variation was found to be $9 \cdot 7 \%$ (range $9 \cdot 1-12 \cdot 1 \mu \mathrm{mol} / \mathrm{l}$, mean $=10 \cdot 3, S E=0 \cdot 33$ ). To increase the precision of the assay triplicate blood samples were assayed at each time point during the study.

All subjects gave their informed consent and the experimental protocol was approved by the local ethical committee.

\section{STATISTICAL METHODS}

Differences between means were compared using the Student's $t$ test. Values shown are means and the standard error of the mean. In all Figures * indicates $\mathrm{p}<0.05$ and $* *$ indicates $\mathrm{p}<0.01$.

\section{Results}

Figure 2 shows the relationship between blood ethanol concentrations and time for patients with alcoholic and non-alcoholic liver disorders and controls after ethanol challenge. The curves are similar although values were significantly raised at 30 minutes for the ALD group. Figure 3 shows the acetaldehyde concentration/time curves in the three study groups. Acetaldehyde concentrations were significantly raised at every half-hourly point in ALD patients and at $30,60,150$, and 180 minutes in NALD patients. Mean blood acetaldehyde concen-

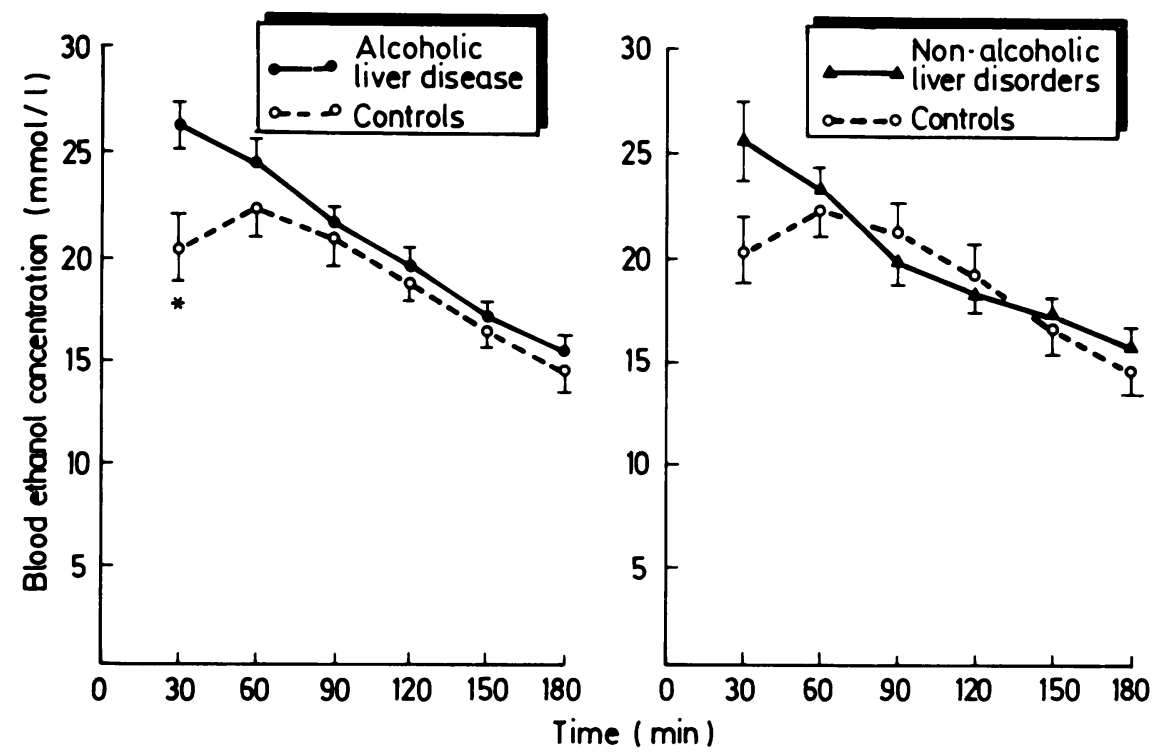

Fig. 2 Blood ethanol concentration/time curves for alcoholic liver disease $(n=14)$, non-alcoholic liver disorders $(n=14)$ and controls $(n=12) .\left({ }^{*} p<0.05\right)$. 


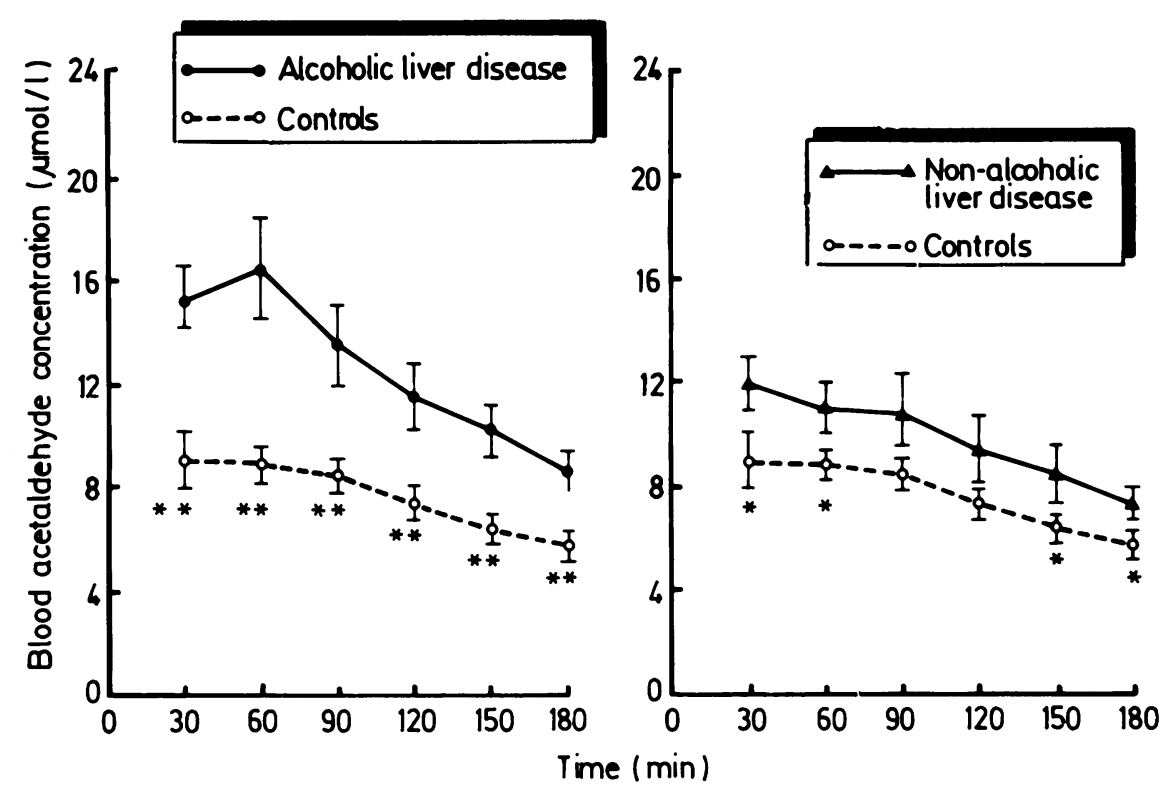

Fig. 3 Blood acetaldehyde concentration/time curves for alcoholic liver disease $(n=14)$, non-alcoholic liver disorders $(n=14)$ and controls $(n=12) .\left({ }^{*} p<0 \cdot 05,{ }^{* *} p<0 \cdot 01\right)$.

trations (30-180 minute values) in each study group are shown in Figure 4. There were significant rises in the two patient groups compared with controls but no significant differences were seen between patients with (ALD and NALD) and without (ALD and

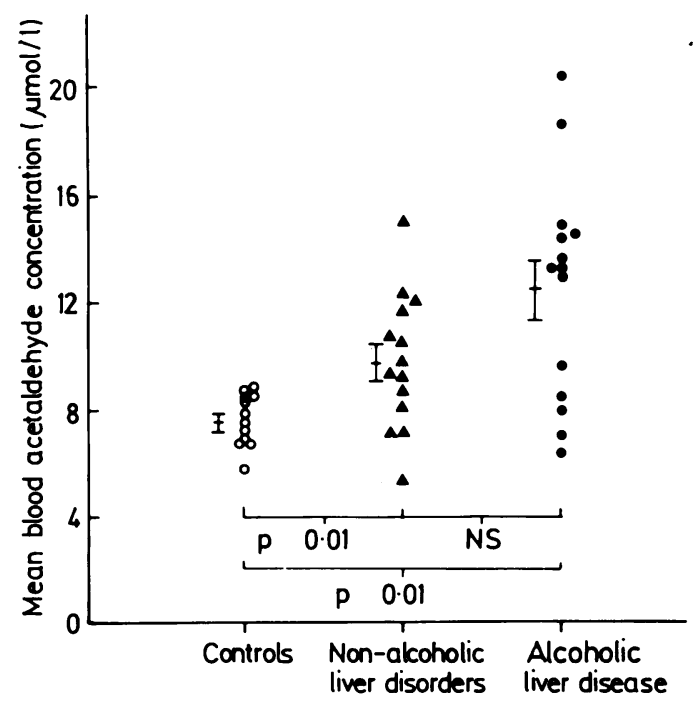

Fig. 4 Mean blood acetaldehyde concentration after ethanol in patients with alcoholic liver disease, nonalcoholic liver disease and control subjects.
NALD) cirrhosis $(11 \cdot 6 \pm 1 \cdot 2$ vs $10 \cdot 9 \pm 0 \cdot 28 \mu \mathrm{mol} / \mathrm{l}$ respectively).

The results of the hepatic cytosolic aldehyde dehydrogenase assays are shown in Figure 5. Significant decreases in enzyme activity were seen in patients with ALD, CAH and paracetamol poisoning. There was a highly significant decrease when the NALD group as a whole was compared with the controls ( $<<0.001$; Table 3 ). Both ALD and NALD patients had decreased alcohol dehydrogenase activity when compared with controls $(\mathrm{p}<0.01$ in both groups) but no decreases in lactate dehydrogenase activity were seen in either of the groups studied (Table 3). Hepatic cytosolic aldehyde dehydrogenase activity in ALD patients who were actively drinking was $7.9 \pm 0.72 \mathrm{mU} / \mathrm{mg}$ compared with $12.5 \pm 1.53$ in the ALD patients who were currently abstaining $(p<0.02)$, although the activity of the latter group was still significantly lower than controls $(p<0 \cdot 01)$. When patients were divided into cirrhotic versus non-cirrhotic, no differences in enzyme activity were evident $(10.7 \pm 0.9$ vs $10.9 \pm 1.1 \mathrm{mU} / \mathrm{mg}$ respectively).

In subjects who had both ethanol loading and liver biopsy studies there was a significant inverse correlation between mean blood acetaldehyde concentration during the 180 minutes after ethanol and aldehyde dehydrogenase activity (Fig. 6). No such correlation was found between mean acetaldehyde concentration and cytosolic alcohol dehydrogenase 


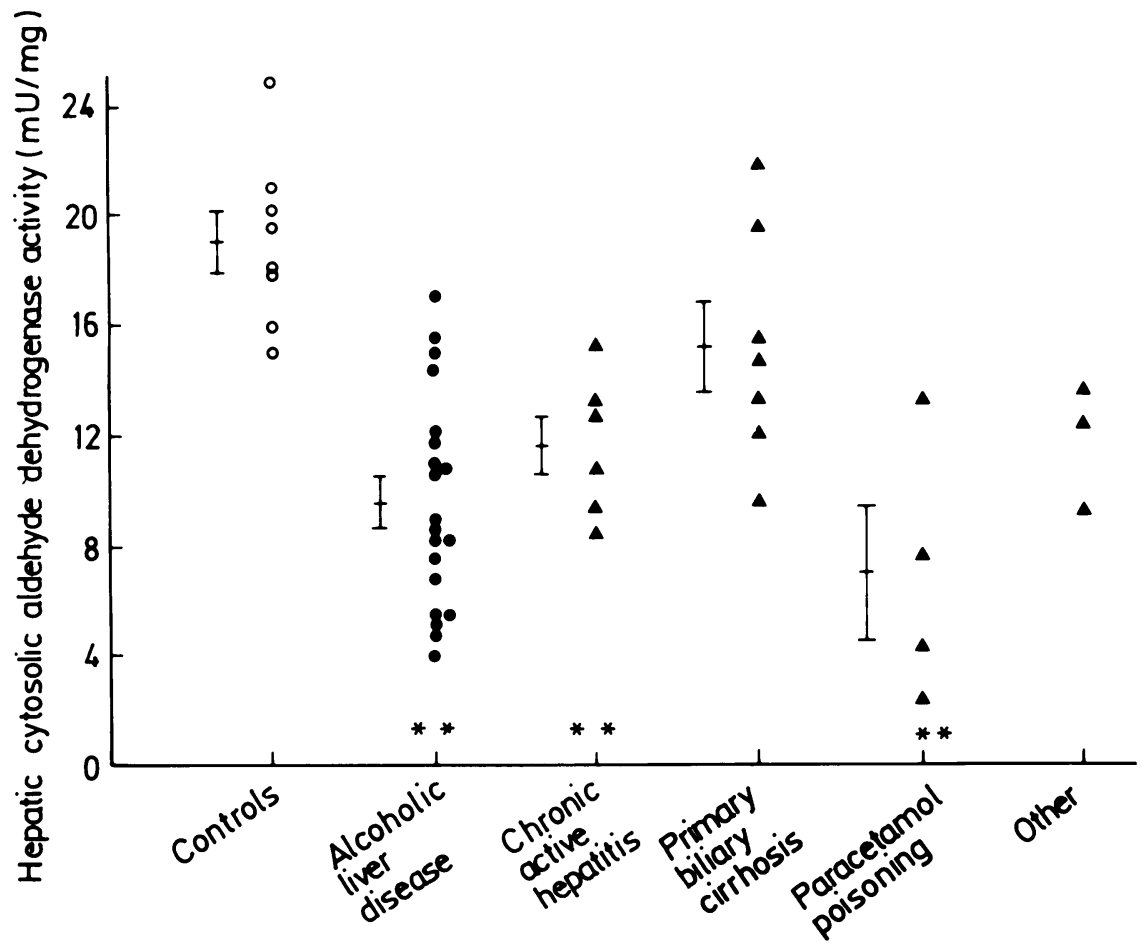

Fig. 5 Hepatic cytosolic aldehyde dehydrogenase activity in patients with alcoholic liver disease, non-alcoholic liver disorders and controls. $\left({ }^{* *} p<0 \cdot 01\right)$.

activity $(r=0 \cdot 056)$ or mean blood ethanol concentration and alcohol dehydrogenase activity $(r=-0 \cdot 11)$.

\section{Discussion}

The results confirm that patients with alcoholic liver disease have reduced cytosolic aldehyde dehydrogenase activity. ${ }^{11} 12$ They also indicate that

Table 3 Enzyme activities ( $\mathrm{mU} / \mathrm{mg}$ ) in patients with liver disease and control subjects

\begin{tabular}{llll}
\hline & \multicolumn{3}{l}{ Liver Diseases } \\
\cline { 3 - 4 } & $\begin{array}{l}\text { Controls } \\
(8)\end{array}$ & $\begin{array}{l}\text { Alcoholic } \\
(20)\end{array}$ & $\begin{array}{l}\text { Non-alcoholic } \\
(20)\end{array}$ \\
\hline $\begin{array}{c}\text { Aldehyde } \\
\text { dehydrogenase }\end{array}$ & $19 \cdot 0 \pm 1 \cdot 1$ & $9 \cdot 6 \pm 0 \cdot 9$ & $12 \cdot 1 \pm 1 \cdot 0$ \\
$\begin{array}{c}\text { Alcohol } \\
\text { dehydrogenase }\end{array}$ & $114 \pm 14$ & $64 \pm 10$ & $65 \pm 10$ \\
$\begin{array}{c}\text { Lactate } \\
\text { dehydrogenase }\end{array}$ & $277 \pm 27$ & $261 \pm 22$ & $268 \pm 21$ \\
\hline
\end{tabular}

Values of alcohol and aldehyde dehydrogenase (mean \pm SEM) in liver disease patients were significantly different from controls $(\mathrm{p}<0.01)$. patients with a variety of non-alcoholic liver disorders have a similar abnormality. This finding is in contrast with that of Palmer and Jenkins ${ }^{11}$ who studied total aldehyde dehydrogenase activity (includes mitochondrial as well as cytosolic activity) in eight patients with non-alcohol related liver disorders and found no significant decrease in enzyme activity. Palmer and Jenkins used a gas chromatographic enzyme assay but their data show that there is a very close correlation between results from the chromatographic technique and from the spectrophotometric technique used by us. ${ }^{20}$ The differences between the results are probably explained by the severity of the liver disease in our group, the greater number of subjects studied and our concentration on the cytosolic fraction where at least in alcoholics, decreases in enzyme activity are more pronounced. ${ }^{12} 13$ Jenkins et $a l^{21}$ studied hepatic aldehyde dehydrogenase activity in alcoholics who became abstinent and found a significant increase in enzyme activity. They concluded that alcohol itself was the cause of depressed enzyme activity. Although our abstaining alcoholic liver disease patients had significantly higher values than the active drinkers, they were significantly decreased 


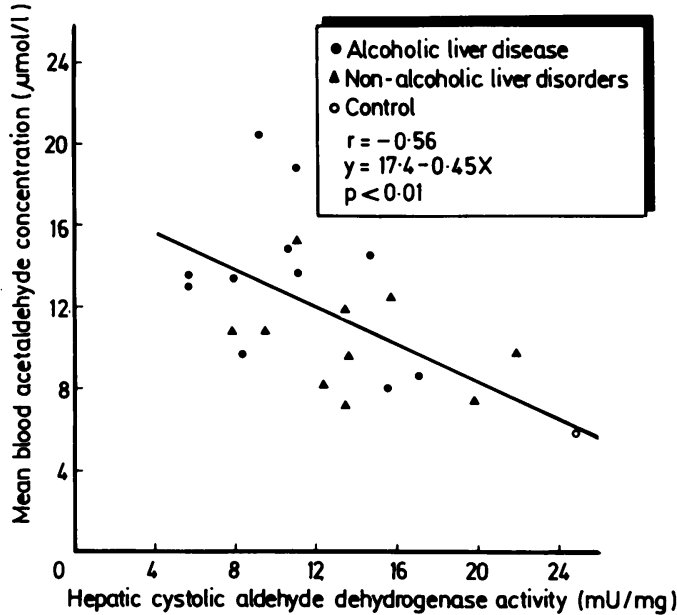

Fig. 6 Correlation between mean blood acetaldehyde concentrations (30-180 min values) and hepatic cytosolic aldehyde dehydrogenase activity.

compared with the controls suggesting that enzyme activity can remain low in the absence of continuing ethanol consumption. Our results also show that the abnormality is not specific to alcoholics but occurs in a variety of acute and chronic liver disorders, confirming that it is a consequence of liver disease rather than a pre-existing abnormality which predisposes to alcoholism or alcoholic liver disease as suggested by Thomas et al. ${ }^{13}$ One might therefore expect patients with the most severe liver damage to have the lowest aldehyde dehydrogenase activity and might therefore have expected cirrhotics to have lower enzyme activity than non-cirrhotics but this was not the case. It should be remembered that absence of cirrhosis does not necessarily imply less severe liver damage and indeed some of our paracetamol poisoning patients had very severe damage with marked impairment of liver function, grossly prolonged prothrombin times and encephalopathy. The severity of their damage was reflected in the lowest mean aldehyde dehydrogenase activity found in any of the study groups.

This study also contirms that patients with alcoholic liver disease have raised blood acetaldehyde concentrations after an ethanol load, and suggests a similar abnormality in patients with non-alcoholic liver disorders. It was found impossible to adequately sex match the control group with both the predominantly male ALD group and the predominantly female NALD group. Our control values, however, support published data which suggest that normal women have lower blood acetaldehyde concentrations than normal men after ethanol administration. ${ }^{22}$ This would tend to decrease acetaldehyde concentrations in our NALD group, but despite this values were still significantly raised. This finding of lower blood acetaldehyde concentrations in women may also explain why our NALD subjects tended to have lower blood acetaldehyde concentrations than the ALD subjects.

A major criticism of acetaldehyde assays has been the spontaneous artifactual production of acetaldehyde from ethanol during the assay. The rapid $(5-10 \mathrm{sec})$ quenching of blood in percloric acid containing L-cysteine was found to be essential to prevent this while in addition the subsequent sealing and freezing of the sample on solid carbon dioxide was necessary to avoid losses of acetaldehyde. Recovery studies confirmed that in the present assay these were not significant problems. The refinements in assay technique could account for our finding of lower acetaldehyde concentrations than previously reported. ${ }^{10}$

Like Palmer and Jenkins ${ }^{11}$ we found no evidence of impaired ethanol metabolism in alcholic liver disease patients, nor did we find any such abnormality in non-alcholic liver disorder patients. Peak ethanol concentrations were significantly raised in ALD but not NALD patients. A possible explanation is that ALD patients had altered volumes of distribution for ethanol. This seems unlikely, however, as only one patient had clinically detectable ascites at the time of study and although nutritional status was not assessed for the purposes of this study, there were no grossly obese ALD patients. It is also unlikely that varying rates of gastric emptying were responsible as we specifically excluded subjects with previous gastric surgery and also ethanol is rapidly absorbed from the stomach particularly in fasting subjects such as ours. Although all subjects ingested the ethanol within 10 minutes it is possible that the ALD patients who were more accustomed to taking alcoholic beverages took the ethanol over a shorter period than other subjects, and this may have contributed to the higher peak ethanol concentrations in these subjects.

The absence of accelerated ethanol metabolism in subjects with alcoholic and non-alcoholic liver disorders suggests that raised acetaldehyde concentrations are caused by decreased acetaldehyde metabolism rather than increased ethanol oxidation. Strong corroborative evidence is provided by the significant inverse correlation between mean blood acetaldehyde concentration and cytosolic aldehyde dehydrogenase activity, a finding which confirms that of Palmer and Jenkins. ${ }^{11}$ The fact that we assayed only the cytosolic fraction and found an inverse correlation raises a question about the role of this particular isozyme in acetaldehyde oxidation. 
Jenkins et al ${ }^{21}$ suggest that the mitochondrial enzyme has the most important role to play because its $\mathrm{Km}$ value more closely approximates to the concentrations of acetaldehyde found in vivo. They suggest that the cytosolic enzyme has little part to play because it has a high $\mathrm{Km}$ value in the millimolar range. Some authorities, however, place the $\mathrm{Km}$ value of the cytosolic enzyme for acetaldehyde as low as 32 micromoles. ${ }^{23}$ We suggest that the cytosolic enzyme may be important for three reasons: firstly, although total hepatic aldehyde dehydrogenase levels are decreased in alcoholic liver disease, this decrease is virtually all accounted for by the cytosolic fraction, ${ }^{12}$ and as we have shown a negative correlation between acetaldehyde concentrations and cytosolic activity alone it seems highly likely that this isozyme is at least partially involved in controlling acetaldehyde concentrations; secondly, erythrocytes contain an aldehyde dehydrogenase which is morphologically identical to hepatic cytosolic but not the mitochondrial enzyme and it is capable of metabolising significant quantities of acetaldehyde 2425 ; and finally, the drug disulfiram, which is used as an aversion therapy for alcoholics, raises blood acetaldehyde concentrations by inhibiting only cytosolic aldehyde dehydrogenase, ${ }^{26}{ }^{27}$ again suggesting that the cytosolic enzyme has a significant role to play. The lack of correlation between alcohol dehydrogenase and ethanol concentration and the significant decrease in alcohol dehydrogenase activity in liver disease patients without any alteration in blood ethanol concentrations suggests that factors other than the activity of this enzyme are rate limiting during ethanol oxidation.

We conclude that liver injury, whether the aetiology is alcoholic or non-alcoholic can result in reduced hepatic cytosolic aldehyde dehydrogenase activity, which in turn results in impaired acetaldehyde metabolism and increased blood concentrations after ethanol ingestion. Our results provide a theoretical basis for the oft given advice to patients with non-alcoholic liver disorders to abstain from alcohol.

This study was made possible by a grant from the Scientific and Research Committee of Newcastle Health Authority.

\section{References}

1 Perin A, Scalabrino G, Sessa A, Amaboldi A. In vitro inhibition of protein synthesis in rat liver as a consequence of ethanol metabolism. Biochem Biophys Acta 1974; 366: 101-8.
2 Burke JP, Rubin E. The effects of ethanol and acetaldehyde on products of protein synthesis by liver mitochondria. Lab Invest 1979; 41: 393-400.

3 Tuma DJ, Zetterman RK, Sorrell MF. Inhibition of glycoprotein secretion by ethanol and acetaldehyde in rat liver slices. Biochem Pharmacol 1980; 29: 35-8.

4 Lieber CS. Alcohol, protein metabolism and liver injury. Gastroenterology 1980; 79: 373-90.

$5 \mathrm{Knop} \mathrm{J,} \mathrm{Angelo} \mathrm{H}$, Christensen JM. Is role of acetaldehyde in alcoholism based on an analytical artifact? Lancet 1981; 2: 102.

6 Thomas M, Lim CK, Peters TJ. Assaying acetaldehyde in biological fluids. Lancet 1981; 2: 530-1.

7 Eriksson CJP. Elevated blood acetaldehyde levels in alcoholics and their relatives: a re-evaluation. Science 1980; 207: 1383-4.

8 Lindros KO. Human blood acetaldehyde levels: with improved methods, a clearer picture emerges. Alcoholism: Clin Exp Res 1982; 6: 70-5.

9 Lindros KO, Stowell A, Pikkarainen P, Salaspuro M. Elevated blood acetaldehyde in alcoholics with accelerated ethanol ethanol elimination. Pharmacol Biochem Behav 1980; 13: 101-5.

10 Korsten MA, Matsuzaki S, Feinman L, Lieber CS. High blood acetaldehyde levels after ethanol administration. Differences between alcoholics and nonalcholic subjects. $N$ Engl J Med 1975; 292: 386-9.

11 Palmer KR, Jenkins WJ. Impaired acetaldehyde oxidation in alcoholics. Gut 1982; 23: 729-33.

12 Jenkins WJ, Peter TJ. Selectively reduced hepatic acetaldehyde dehydrogenase in alcoholics. Lancet 1980; 1: 628-9.

13 Thomas M, Halsall S, Peters TJ. Role of hepatic acetaldehyde dehydrogenase in alcoholism: demonstration of a persisting reduction of cytosolic activity in abstaining patients. Lancet 1982; 2: 1057-9.

14 Jenkins WJ, Peters TJ. Mitochondrial enzyme activities in liver biopsies from patients with alcoholic liver disease. Gut 1978; 19: 341-4.

15 Blair AH, Bodley FH. Human liver aldehyde dehydrogenase: partial purification and properties. Can $J$ Biochem 1969; 47: 265-71.

16 Lange LG, Sytkowski AJ, Vallee BL. Human liver alcohol dehydrogenase. Purification, composition and catalytic features. Biochemistry 1976; 15: 4687-93.

17 Reeves WJ, Fimognari GM. Lactate dehydrogenase. Method Enzymol 1966; 9: 288-94.

18 Lowry OH, Rosebrough NJ, Farr AL, Randall RJ. Protein measurement with the folin phenol reagent. $J$ Biol Chem 1951; 193: 265-75.

19 Von Wartburg JP, Ris MM. Determination of acetaldehyde in human blood. Experimentia 1979; 35: 1682-3.

20 Palmer KR, Jenkins WJ. An improved method for the determination of aldehyde dehydrogenase in human liver biopsies using gas chromatography. Clin Chim Acta 1981; 115: 359-62.

21 Jenkins WJ, Cakebread K, Palmer KR. Effect of alcohol consumption on hepatic aldehyde dehydrogenase activity in alcoholic patients. Lancet 1984; 1 : 1048-9.

22 Arthur MJP, Lee A, Wright R. Sex differences in the 
metabolism of ethanol and acetaldehyde in normal subjects. Clin Sci 1984; 67: 397-401.

23 Agarwal DP, Dethling J, Wolken S, Harada S, Goedde HW. Sub-cellular distribution and properties of aldehyde dehydrogenase isozymes in autopsy livers from normals and alcoholics. Alcoholism: Clin Exp Res 1982; 6: 432.

24 Inoue $\mathrm{K}$, Fukunaga $\mathrm{M}$, Yamasawa $\mathrm{K}$, Komura $\mathrm{S}$. Uptake and oxidation of acetaldehyde by intact human erythrocytes. Biochim Biophys Acta 1983; 759: 264-9.

25 Maring JA, Weigand K, Brenner HD, Von Wartburg
JP. Aldehyde oxidizing capacity of erythrocytes in normal and alcoholic individuals. Alcoholism: Clin Exp Res 1982; 6: 433.

26 Greenfield NJ and Pietruszko R. Two aldehyde dehydrogenases from human liver. Isolation via affinity chromatography and characterization of the isozymes. Biochim Biophys Acta 1977; 483: 35-45.

27 Inoue $\mathrm{K}$, Fukunaga $\mathbf{M}$, Yamasawa $\mathrm{K}$. Effect of disulphiram and its reduced metabolite, diethyldithiocarbamate on aldehyde dehydrogenase of human erythrocytes. Life Sci 1982; 30: 419-24. 